\title{
Frontier constellations: agrarian expansion and sovereignty on the Indonesian-Malaysian border
}

\author{
Michael Eilenberg
}

\begin{abstract}
Borderland regions in Southeast Asia have increasingly been reimagined as resource-rich, unexploited 'wastelands' targeted for large-scale development schemes for economic integration and control. Common and overlapping features of these regions are processes of resource extraction, agricultural expansion, population resettlement and securitization, and the confluence of these dynamic processes creates special frontier constellations. Through the case of the Indonesian-Malaysian borderlands, I explore how processes of frontier colonization through agricultural expansion have been a recurrent product of Indonesian development and security policies since the early 1960s. I argue that frontier development accelerates and intensifies when national discourses of security and sovereignty and state-led agrarian expansion intersect along national borders. The study generates new insights into how contemporary statecapitalist processes of agricultural expansion in the borderlands of Indonesia and other parts of Southeast Asia are justified through discourses of national sovereignty and notions of 'untamed' and 'wild' resource frontiers. I highlight the multiple meanings and notions associated with regions where resource frontiers and national borders interlock. The study offers an explanation of how frontiers as discursive constructs and material realities play out along national borders.
\end{abstract}

Keywords: agrarian expansion; frontiers; borderlands; resettlement; sovereignty; security; Indonesia

\section{Introduction: between borders and frontiers ${ }^{1}$}

In 2011, the Indonesian Agency for Border Management (BNPP) $)^{2}$ released a new national regulation named the 'Grand Design' (BNPP 2011). The 'Grand Design' stipulated a 15 -year master plan for economic development, defense and security along the country's

The author thanks Christian Lenz, Jason Cons, Zach Anderson, Christian Lund, Derek Hall, Tania Li, Nancy Peluso and the two anonymous reviewers for their feedback and insightful comments.

${ }^{1}$ Data presented in this study were collected during 25 months of field research in the West Kalimantan borderlands in the period 2002-2012. Interviews were conducted with a wide array of local and national actors ranging from state officials, politicians, non-governmental organizations (NGOs), entrepreneurs and local elites (community heads and tribal heads) to local peasants and plantation workers. Interviews were triangulated with data from government reports and newspaper clippings. The field research was academically sponsored by Tanjungpura University, Pontianak, with permission from the Indonesian Institute of Sciences (LIPI) and the Indonesian Ministry of Research and Technology (RISTEK), Jakarta. The conclusions drawn here are not necessarily those of the above agencies; the author alone is responsible.

${ }^{2}$ Badan Nasional Pengelola Perbatasan or BNPP. Among the members of the BNPP are the Indonesian military commander, the national chief of police, the head of the State Intelligence Agency, the 
neglected border. ${ }^{3}$ Simultaneously, a presidential regulation on national development for the years 2010-2014 targeted the country's border regions. They were to become Indonesia's new centers of economic growth by the year 2014, with large-scale plantation development as the main economic driver (Perpres 2010b). Besides economic development, the presidential regulation highlighted how such large-scale agrarian initiatives would enhance territorial sovereignty and increase the state's presence along the country's porous borders (Perpres 2010b). One of the eight targeted regions was the district of Kapuas Hulu in the province of West Kalimantan, bordering the Malaysian state of Sarawak (Jakarta Post 2011b).

The West Kalimantan borderlands as a whole, and Kapuas Hulu in particular, have a long history of economic underdevelopment compared to other parts of the country and are characterized by a weak socioeconomic infrastructure, isolated regional markets and a scarcity of large-scale investments (Hamid and Widianto 2001). The local economy has been stalled due to lack of relations with and remoteness from the provincial economic center, which in turn has made illegal cross-border trade crucial to the local economy (Wadley and Eilenberg 2005). Furthermore, the ethnic border population is vigorously depicted by government agencies as being especially resistant towards officialdom, because of their involvement in practices of questionable legality and their apparently heightened sense of autonomy (Bappenas 2004, 2006a, 2008). Their general lack of national consciousness makes them more prone to foreign (Malaysian) manipulation and thus a matter of national security (Bappenas 2011).

With the introduction of the new border regulations, the Indonesian government plans to boost economic development and security in the 'remote and underdeveloped' borderlands through large-scale investments in infrastructure, mining and agricultural expansion, carried out in cooperation with the private sector and the military (BNPP 2011). According to the director general of plantations at the Ministry of Agriculture, the only way to create a 'prosperous border region is to establish oil palm plantations' (Media Perkebunan 2011). 'Wastelands' along the border should be reintegrated into the sovereign nation-state and local populations nationalized through the allocation of private oil palm concessions and firm military intervention (BNPP 2011). In line with the government plan, the Indonesian Armed Forces publicly announced that they would increase their presence in the border regions by establishing new military commands and infantry divisions in order to take control of the 'lawless' borderlands and protect abundant natural resources from foreign (Malaysian) intrusion (Jakarta Post 2010). By focusing on these recent processes of remilitarization along the border, I show how the Indonesian military is repositioning itself in the lucrative role of protector of national sovereignty, working in tandem with private transnational capital.

The increased government focus on border development is the latest chapter in a long and contested history of resource exploitation and militarization in the Indonesian border regions since the early 1960s. It illustrates the intimate linkages between policy regimes of national development and discourses of territorial sovereignty and security. This study investigates these linkages and their contested nature and highlights how contemporary

head of the Coordinating Agency for Surveys and Mapping and relevant governors. The home minister is assigned as head of the BNPP (Perpres 2010a).

${ }^{3}$ The same year, the agency received no less than 149 billion rupiah (USD 15.5 million) to coordinate the development of the border regions. The following year the government allocated 2.8 trillion rupiah to the project (USD 316.4 million), an increase of 2000 percent (Jakarta Post 2011a). 
processes of agricultural expansion in the West Kalimantan borderlands are repeatedly justified through government discourses of national sovereignty, security and powerful notions of 'wild' and unexploited resource frontiers. Large-scale development projects, such as the projects planned and currently executed along the Indonesian-Malaysian border, can be seen as elements of what James Scott calls 'state simplification', which is above all concerned with issues of legitimacy and, ultimately, the increase of state control (Scott 1998). 'High-modernist' state schemes like mega-plantations and transmigration towns are largely based on a simplified view of the landscape that deliberately realigns relations between people and space, often with unintended consequences.

As indicated above, military involvement in resource extraction and population resettlement in Indonesia and Southeast Asia as a whole is not a novel phenomenon and can be traced back to the counterinsurgencies of the Cold War era, when many of the burgeoning Southeast Asian nation-states were plunged into violent conflict. The rugged and forested borderlands often became insurgent hideouts and thus key battlefields in the war against communism and communist regimes (Dennis and Grey 1996, Subritzky 2000, Jones 2002, Tuck 2004), instigating processes of violent resettlement, resource exploitation and firm military control (De Koninck 2006). As argued by Nancy Peluso and Peter Vandergeest, counterinsurgency measures in forest frontiers in Southeast Asia (especially along national borders) have played a crucial role in state territorialization of forest resources (2011) Many of these forestlands have since been under various forms of military control and have become zones for economic exploitation, generating revenue for the military budgets (Peluso 2008, Eilenberg 2011). Despite the fact that many of these resourcerich borderlands are increasingly being targeted for large-scale development schemes and territorial control in a way that resembles past government strategies of securitization (Geiger 2008), so far only a few studies have critically engaged with the intricate links between emerging agricultural expansion and militarization in the borderlands (see for example Ito et al. 2011, Woods 2011, Laungaramsri 2012). Furthermore, current debates on 'land grabs' in Southeast Asia have given much attention to the circuits of transnational capital and issues of land tenure and labor regimes, while the effects of national policies of militarization and securitization remain understudied (Borras and Franco 2011, Hall 2011, Li 2011).

In an attempt to trace the linkages between agrarian expansion, sovereignty and securitization along the Indonesian-Malaysian border, I will introduce the notion of 'frontier constellations' as an analytical starting point and highlight the multiple meanings and notions associated with regions where resource frontiers and national borders interlock. I argue that such frontier constellations in Southeast Asia are distinctive social, economic and political formations with multiple meanings, such as (1) political borderlines separating two or more nation-states, (2) areas physically separate from state cores and (3) zones between allegedly settled and unsettled land, accentuating underdevelopment, remoteness and dense forest landscapes. I argue that scrutinizing this specific frontier constellation provides insight into state-led notions of development and sovereignty. As expressed by Nils Fold and Philip Hirsch $(2009,95)$, 'The frontier is thus in part a metaphor for national development in its material and ideological senses, as well as in terms of spatial expansion and delimitation'.

The combination of resource frontiers (a moving zone) and national borders (a fixed line) is intriguing, because in much of the literature on frontiers and borders the two are kept firmly apart and often used as opposing concepts. According to Danilo Geiger (2008, 95), frontier spaces are not necessarily situated along national borders, but when they are, 'we are dealing with a special constellation rather than a definitional criterion 
for "frontierness"'. Building on work that conceptualizes frontiers as "myth, analytical framework and material reality' (Redclift 2006, viii), I argue that the frontier imaginary becomes especially powerful and potent in regions where resource frontiers and national borders interlock. This is especially so as these zones of immense natural resources and sparse populations currently play an important role as the territorial and economic spearhead of many Southeast Asian states. In other words, by bringing together the issues of frontiers, borderlands and agrarian expansion and grounding them in extensive empirical research, I wish to direct attention to novel forms of state making and securitization in Southeast Asia and contribute to debates on agrarian change at the margins of developing states (De Koninck 2006, Barney 2009, Hirsch 2009, Woods 2011).

First, I will provide analytical grounding to the concepts of frontiers, borders and borderlands. This analysis will go on to address in detail past and current dynamics of frontier expansion and sovereign politics on the Indonesian-Malaysian border on the island of Borneo by examining cases of large-scale resource extraction, plantation development and resettlement schemes in the Indonesian province of West Kalimantan. I will demonstrate that recent border development initiatives are just the latest chapter in a long and contested history of border development and territorial sovereignty in Indonesia. Crucially, I intend to highlight how frontiers, as imaginary as well as physical reality, are constructed and transformed at the intersection of a number of processes, such as capitalist resource exploitation, state-sponsored schemes and issues of territorial sovereignty. I will conclude by addressing the implications of the current processes of agrarian expansion and militarization in the Indonesian-Malaysian borderlands.

\section{Conceptualizing frontiers, borders and borderlands}

Frontiers, borders and borderlands have often been used as interchangeable concepts. Hence, before turning to the substantive matter of the paper, I will explore the problems of conceptualization and definition. When I use the concept of borders, I refer to the line that separates two nation-states, the borderlands being the regions, of varying widths, immediately adjacent to or bisecting this line (Donnan and Wilson 1994, Baud and van Schendel 1997). Broadly speaking, what characterizes a border region is its close proximity to a national borderline as well as the direct and significant effect, economic, social and political impact this border has on life in the region (Haller and Donnan 2000). For example, weaker states like Indonesia are often unable to make their claims stick when the borderlands lack infrastructure, are covered in forest and are sparsely populated. Hence, the consolidation of territorial sovereignty, i.e. 'the recognition of the claim by a state to exercise supreme authority over a clearly defined territory' (the Westphalian ideal) (Zaum 2007, 3), is high on government agendas. Borders become the raison d'être of state sovereignty. This classical definition of sovereignty, which presupposes a strong 'unitary' state imposing unlimited control on a clearly defined territory, is a potent trope that plays a prominent role in state development discourses in border regions (Jones 2009, Hagmann and Korf 2012). This classical definition of sovereignty has, of course, been widely questioned by scholars who have taken up the challenge of conceptualizing the state as fragmented and a series of effects rather than an a priori homogeneous whole. For example, in Siam mapped, Thongchai Winichakul (1994) show how fixating national borders through administrative technologies of mapping created the myth of a unified modern Thai nation-state, or 'geo-body'. However, despite the deconstruction of the 'unitary state', most scholars still recognize that the 'idea' of the unitary state with clear boundaries and territory still plays a major role as a potent symbol of power and as a recognized set of practices that have 
material effects in maintaining territorial power (see, for example, Migdal 2004, Hansen and Stepputat 2006, Lund 2011). Furthermore, as argued by Tobias Hageman and Benedikt Korf, state practices of territorialization through land appropriation often form the backbone of the exercise of sovereignty at the margins of the state (Hagemann and Korf 2012). These practices of territorialization often take place through military practice and force and precede the commoditization of resources within those territories (Vandergeest and Peluso 1995). For example, Giorgio Agamben stresses that sovereign power is not only about maintaining a legal monopoly of violence over a defined territory; it is also a means of suspending the rule of law through a 'state of emergency'. In the case of West Kalimantan, this means excluding people from rights to land and resources through increased securitization and military intervention in the borderland, in the name of national sovereignty (Agamben 2005). Investigating such logic of state interventions, the practice of governance and the borderlands' entangled power relations thus aid an understanding of governmental rationality and its exercise by various authorities, attempting to govern borderland societies in the name of development (Van Schendel 2005, Walker 2006, Ishikawa 2010).

Like the concepts of border and borderlands, the frontier concept has a long and ambiguous history and has been widely applied (often unreflectively) as a heuristic device to describe processes of transition, exclusion and inclusion, both physically and figuratively. The extensive literature on frontiers involves many disciplines, and as there are just as many ways of approaching the subject, this lack of conceptual consensus has made any definition of the concept a challenging endeavor (Baud and van Schendel 1997). Furthermore, adding to the confusion, in an English and American tradition the word 'frontier' is often used to denote literal borderlines, borderland regions and the process of territorial expansion of state authority or civilization into remote 'wastelands' (Wendl and Rösler 1999). The frontier approach of this study is primarily inspired by the latter definitions. It resonates well with recent anthropological and geographical studies that embrace different attempts to conceptualize frontiers as (1) a discourse of state imaginaries of opportunistic wilderness and infinite unexploited resources (Tsing 2005, Geiger 2008) and (2) moving zones of state control, agrarian expansion and resource extraction (Fold and Hirsch 2009, McCarthy and Cramb 2009, Baird 2011, De Koninck et al. 2011).

In the Indonesian context, Anna Tsing, among others, has critically observed how the inherent notion of resource frontiers, as 'spaces of desire' with promises of a virgin wilderness and unlimited natural resources, and the implicit notion of expansion have contributed to opening the uplands of Kalimantan for capitalist claims and justified large-scale resource extraction (Tsing 2000, 2003). The frontier as discursive trope thus serves to legitimize processes of 'freeing' land for extraction, exclusion and dispossession: that is, the dispossession of indigenous people from customary lands, the extraction of local forest resources and exclusion from access to land and resources. Ultimately, 'frontiers create wildness so that some - and not others - may reap their rewards' (Tsing 2005, 27). Tsing demonstrates that resource frontiers are projects in the making, which are 'notoriously unstable' and continually change in accordance with global market demands and capitalist claims (Tsing 2003, 5101). As eloquently put by Danilo Geiger, 'Frontiers recede and advance in relation to changing demands for frontier commodities on regional and world markets' (Geiger 2008, 93). Keith Barney (2009) has recently named this strong connection between global market demands, intensive resource extraction and new state-private land enclosures along contemporary Southeast Asian borders 'frontier-neoliberalism'. Drawing on the case of Laos, Barney argues that state agencies 
utilize the discourse of the 'last frontier' as a strategy for attracting transnational investment and legitimating the conversion of its uplands into capital-intensive resource extraction zones (Barney 2009).

Consequently, frontier processes should be seen as cyclical phenomena that wax and wane according to the strength of the state and the pressure of global markets. Hence, in this study, frontiers are defined as the discursive notion or shifting process of territorial expansion (of ostensible civilization) into marginal areas or what may be perceived as empty lands, justifying the extraction of resources and the exclusion of locals by settlers and state planners.

In the West Kalimantan borderland, the discursive construction of the 'wild frontier' has largely facilitated the expansion of large-scale oil palm cultivation, which has drastically altered local landscapes. By combining the above approaches to frontiers and adding the issues of securitization, sovereignty and transnational capital, I aim to generate novel insights into the contested character of these frontier configurations as they appear along contemporary borders in Southeast Asia.

\section{Security and sovereignty through frontier colonization in West Kalimantan}

The Indonesian province of West Kalimantan on the island of Borneo shares 966 kilometers of its land border with the Malaysian state of Sarawak; about 25,168 square kilometers or 16 percent of the total landmass of the province (see Figure 1). ${ }^{4}$ In 2011, the total population of the West Kalimantan borderlands was estimated to be about 180,000 , with an average population density of seven people per square kilometer (Bappenas 2011). The indigenous inhabitants of the West Kalimantan border hills are a mixture of ethnic Dayak $^{5}$ groups, primarily practicing swidden agriculture supplemented with small-scale rubber tapping and circular labor migration across the border with Sarawak (Eilenberg and Wadley 2009). Apart from the main border avenues, for example between Nanga Badau (Indonesia) and Lubok Antu (Sarawak) (which locals have used for centuries), the low-lying hills along the border are easily crossed and constitute no physical barrier. It is estimated that there are more than 50 small back roads into Sarawak. Upriver, in close proximity to the border, the area is dotted with small hills largely covered by secondary forest in different stages of growth - a result of generations of swidden cultivation and, in recent times, commercial logging (see Figure 2).

The sparsely populated borderlands are widely forested and contain large patches of land classified in government policy narratives as 'sleeping', 'waste' or 'idle', waiting to be colonized and exploited for agricultural development and security reasons (Jakarta Post 2005b, Wakker 2006, Potter 2009). Subsequently, the popular 'image' of the borderlands, as seen by outside influences such as government officials and plantation companies, is of a thinly populated resource frontier, separating civilization from 'wilderness', inhabited by an underdeveloped and 'uncivilized' population (Kepmenhut 2004). From this point of view, the 'wilderness' is an 'empty' area, a place just waiting to be conquered and exploited. However, as noted by Andrew Walker, such images of the untamed frontier or wilderness "often have more to do with the anxieties (and fantasies) of the "centre" than with the social and cultural realities of the "periphery" (1999, 9). For example, two

\footnotetext{
$\overline{{ }^{4} \text { On the island of Borneo, the Indonesian-Malaysian land border constitutes } 1840 \text { kilometers trans- }}$ cending the two Indonesian provinces of West and East Kalimantan.

${ }^{5}$ Dayak is an umbrella term for the indigenous population of Kalimantan.
} 


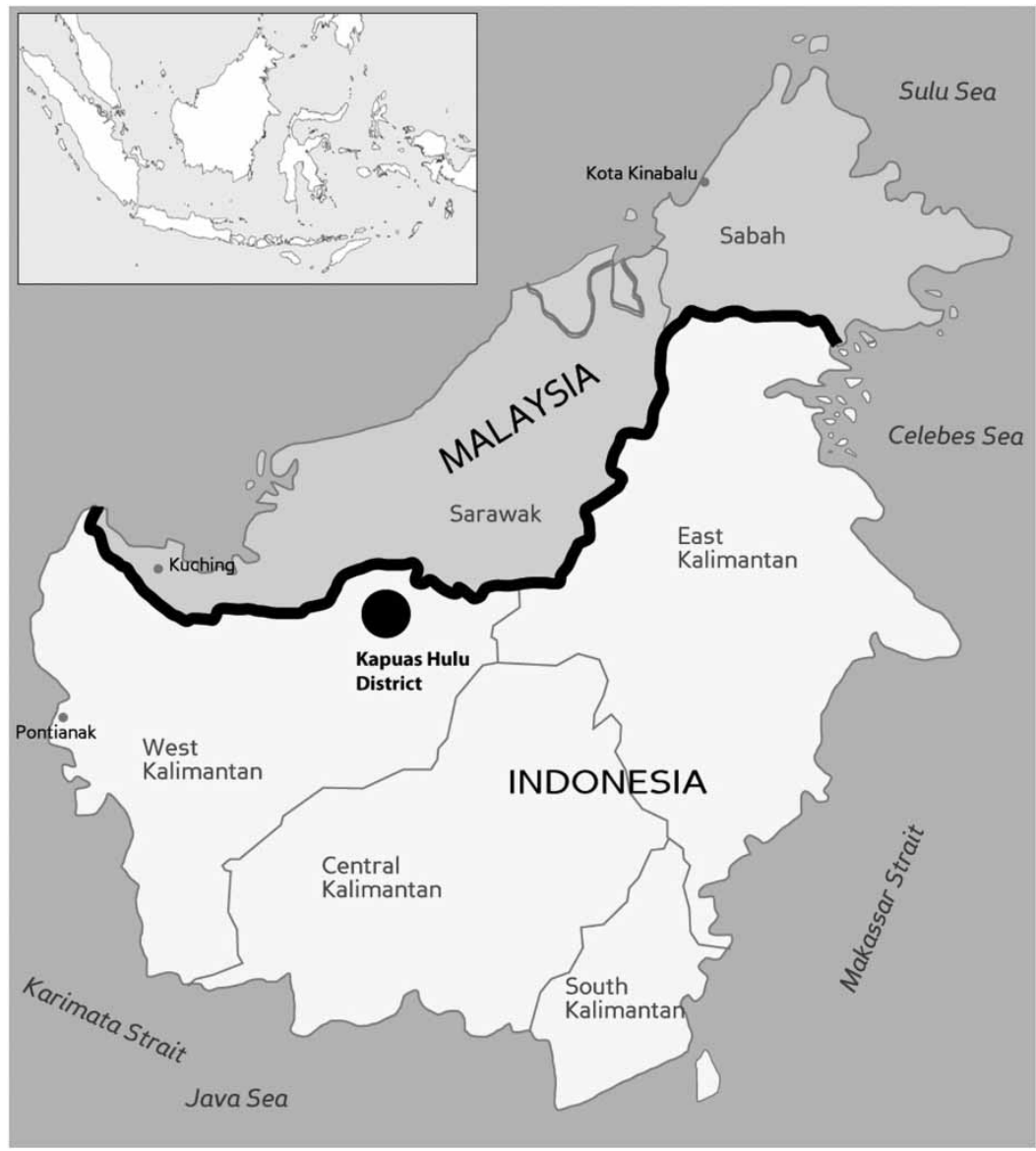

Figure 1. Map of Borneo.

Indonesian journalists who visited the remote West Kalimantan borderland in the heyday of illegal logging in 2004 wrote:

There is a bustling atmosphere in the border town of Badau; crowds of people working the sawmills that line the border mingle with locals at the main market, many of whom carry their shotguns and pistols wide open in public. The town is floating with counterfeit money, drugs and hard liquor, and prostitution is mushrooming in the mold of the rainy season. This is definitely a place without law and without government. Welcome to the world of the tough cowboys. (Sinar Harapan 2004)

The newspaper article vividly describes their first encounter with Badau: a typical example of the popular image of a border town, accentuating lawlessness, violence and underdevelopment. This portrayal of the borderlands as a wild frontier inhabited by rough and triggerhappy frontiersmen, and with no state presence, is common in journalistic and government accounts of conditions in the borderlands. It has provided powerful and pervasive tropes in legitimizing top-down development schemes in the name of 'progress'. 'Frontier' development has been a persistent element in shifting government agendas. Nationally (and regionally) the borderlands are seen as 'backward' and 'left behind' compared to current national 


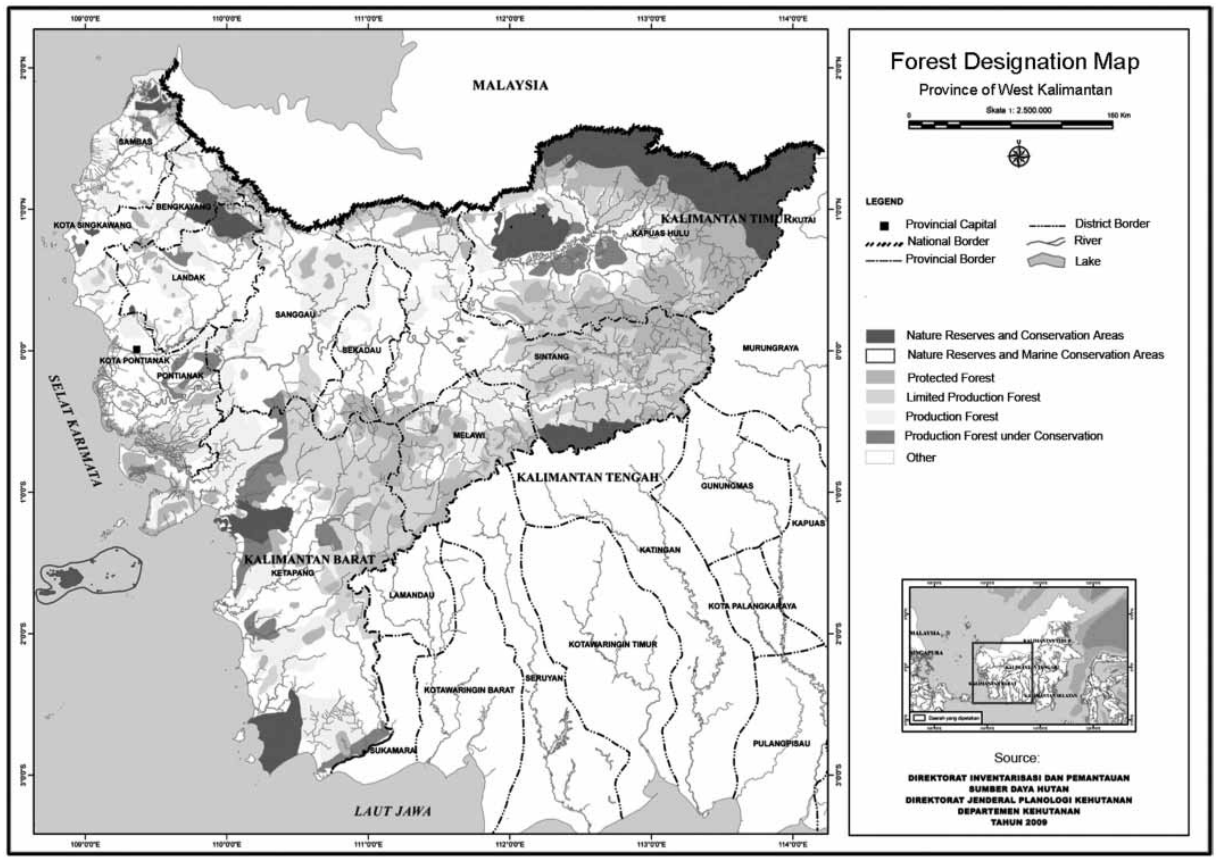

Figure 2. Map of forest cover in West Kalimantan, 2009.

development and they are consequently classified as an area of 'high poverty' (PKB 2005a, KNPDT 2007). Underdevelopment and poor infrastructure along the border with Malaysia, together with the increase in illegal logging and smuggling, have long been considered a national security problem by the central state.

Since the early 1960s, the Indonesian state has struggled to assert control over its national border with Malaysia and its natural resources, presenting arguments of national security and development promotion to the 'estranged and backward' frontier inhabitants (Wadley 2005, Eilenberg 2012a). For example, in 1963, the Kalimantan borderlands became heavily militarized as a result of an armed confrontation (Konfrontasi) between Indonesia and Malaysia, which was followed by a communist insurgency in the mid1960s and the 1970s (Jones 2002, Eilenberg 2011). Ever since, border development and security has been a dominant state discourse and, until the early 1990s, the forested borderlands were categorized as a 'safety belt' or security buffer zone facing neighboring Malaysia (Soemadi 1974). Access for civilians not residing in the borderland region was largely restricted, and access permits from military and police were needed. Consequently, the Indonesian state purposely delayed infrastructural and other kinds of development (Wadley 1998). More to the point, successive Indonesian governments have since allocated large-scale timber and plantation concessions along its resource-rich national border to military entrepreneurs, local elites and private companies as part of a pragmatic frontier colonization and resource extraction strategy (Davidson and Kammen 2002, Eilenberg 2009, Potter 2009). The allocation of concessions was thus part of a nationwide policy of 'nationalizing' ethnic customary lands in unruly forest frontiers. In the case of the IndonesianMalaysian border, the appropriation of land was an additional tool for imposing territorial sovereignty and displaying state authority (Harwell 2000, Peluso and Vandergeest 2011). Additionally, in return for awarding the military this opportunity for economic gain, 
President Suharto received military support in ensuring strict conformity to his New Order politics in the outer regions of the nation (Brown 1999, Human Rights Watch 2006).

So-called 'development' often became an excuse for large-scale resource extraction. For example, in 1967, former President Suharto allocated concession rights to a huge tract of land, covering more than 1 million hectares, to a foundation created by the Indonesian Armed Forces, named 'Yayasan Maju Kerja' or Yamaker. ${ }^{6}$ Despite being the principal permit holder, Yamaker possessed little forestry experience and did not have the required knowledge and financial resources to carry out productive logging. Therefore, it often leased out its concessions to various timber contractors, both Indonesian and Malaysian. In West Kalimantan, Yamaker combined economic exploitation with national security concerns, and its operations encompassed a stretch of border from Tanjung Datu, the westernmost tip of the province on the coast, to the upper part of the Embaloh River to the far east, about 843,500 hectares in area and 400 kilometers in length. ${ }^{7}$ The foundation's main activity was logging to generate income for the armed forces. In return for the concessions, though, the foundation was officially required to improve the socioeconomic welfare of the border communities by promoting various rural development programs. ${ }^{8}$ Yamaker did not fulfill its promises of developing the area and providing local jobs, and repeatedly blocked access to the land on the pretext of security. For local communities the benefits were few. Today most people still recall the Yamaker logging operations with resentment. ${ }^{9}$

Decades later, in 1994, President Suharto issued the first official presidential decree on development initiatives in the border areas of Kalimantan (Indonesian Borneo) (Keppres 1994). According to the decree, border development was imperative for national security, and the approach taken should therefore involve a system of defense and security. The 1994 decree appointed a special 'Agency for the Implementation and Control of Development in the Border Area, BP3WPK'. ${ }^{10}$ This agency involved various ministries, but - tellingly was mainly headed by the Ministry of Defense and Security (Dephankam). Although grand development plans for the border area, including opening the area to transmigration settlements, mining and plantations, were put forward, any genuine commitment to the noble cause quickly died away. The only process that took place in the borderlands was largescale forest resource extraction, of which local communities benefited little (Wadley 1998). ${ }^{11}$

\section{From centralized governance to regional autonomy}

The dynamics of resource extraction abruptly changed in 1998 with the resignation of President Suharto. The new Indonesian reform government came under immense pressure to take a stand against the government structure of the former authoritarian regime and not least the powerful role of the military in domestic politics and business. ${ }^{12}$ The new

\footnotetext{
${ }^{6}$ Decree of the Ministry of Agriculture, 1 November 1967 (HPH No. Kep/79/11/1967).

${ }^{7}$ Yamaker was also given 224,000 hectares of forest in neighboring East Kalimantan. Combined with the concessions in West Kalimantan, this added up to more than 1 million hectares (Obidzinski et al. 2007).

${ }^{8}$ Surat Keterangan, Dewan Pengerus Yayasan Maju Kerja, No. 165/Kep/P.Y/X/1980.

${ }^{9}$ Interviews with Dayak community heads, June 2007.

${ }^{10}$ Badan Pengendali Pelaksanaan Pembangunan Wilayah Perbatasan, BP3WPK.

${ }^{11}$ Interviews with Dayak community members, September-October 2002.

${ }^{12}$ During the Suharto regime, the military was encouraged to uphold a dual function (dwifungsi) as both defense force and social force in civilian politics (Crouch 2007). For example, in the province of West Kalimantan, all governors and district heads were appointed within the military. The military was present in all layers of society.
} 
government instantly began initiating national programs of decentralization, which gave districts increased autonomy (Aspinall and Fealy 2003). As part of the decentralization process, Suharto's successor, President Habbie, issued a new presidential decree revoking his predecessor's decree No. 44/1994 on border development (Keppres 1999). The new decree stated that the BP3WPK team headed by Dephankam had been completely ineffective and had achieved no development goals. Consequently, all of the agency's authority was revoked and divided among an unspecified number of government agencies. The revocation of BP3WPK's authority also resulted in the total termination of Yamaker's timber concessions along the border, and the concession rights were subsequently transferred to the state-owned PT. ${ }^{13}$ Perum Perhutani. (Kepmenhut 1999) the military nonetheless retained ties to the borderlands, although in a less conspicuous manner:

The rights of Yamaker were withdrawn. Actually, the generals are still in the game. They are involved in all processes of those illegal activities; in fact, those were not illegal because they got permission of some generals who were involved themselves. We just cannot prove it. ${ }^{14}$

The new concession holder, the Perhutani, partnered with the Inkopad army cooperative that had logging operations within the former Yamaker site. The military also provided security for Perhutani. ${ }^{15}$ Instead of directly engaging in logging operations, the military collaborated with foreign investors from Malaysia. With a main focus on plantations, however, Perhutani did not possess the required know-how to continue timber extraction and consequently withdrew its operations (Eilenberg 2009). ${ }^{16}$

In 2000, a year after the implementation of the decentralization reforms throughout Indonesia, industrious private timber entrepreneurs, in tandem with corrupt district officials, promptly filled the power vacuum that had occurred in the West Kalimantan borderlands, after the withdrawal of Perhutani and the general confusion created by the rapid distribution of authority from central to district governments. These timber entrepreneurs promptly created a network for large-scale 'illegal' logging and smuggling of valuable timber across the border to Malaysia (Wadley and Eilenberg 2005). ${ }^{17}$ 'Illegal' is here deliberately placed in quotation marks, because most of the logging operations that took place along the border were unauthorized by the central government. ${ }^{18}$ The central government accused district governments of mismanaging the nation's forest resources by collaborating with Malaysian timber entrepreneurs, leading to an increase in illegal logging and corruption. However, district government and border communities considered timber harvesting legal and justified by the 1999 laws on regional autonomy. Thus, the cross-border timber commerce continued

\footnotetext{
13،"PT" stands for "Perseroan Terbatas" (Indonesian: Limited Liability Company).

${ }^{14}$ Interview with Dayak community head, March 2007.

${ }^{15}$ Interviews with district official, October 2002.

${ }^{16}$ Perhutani used to be a Java-based operation specializing in teak and mahogany (Peluso 1992).

${ }^{17}$ During the post-Suharto 'illegal' logging boom in the borderlands, the military, although not visibly, was engaged in the timber business, mostly receiving benefits for keeping their eyes shut (interview with timber broker, February 2003). See also Jakarta Post (2012).

${ }^{18}$ To understand such activities only as 'subversive', however, is to oversimplify the relationship between border communities and the state. Agents of the state, like the military, often collude to maintain such subversive activities because of the economic benefits they bring. As argued by Walker, 'State policy itself may lend tacit support to some of these activities, not as a matter of official and publicly declared goals, but in its practice and uncodified modus operandi ...' $(1999,105-6)$.
} 
until 2005, when large numbers of military and police personnel were stationed along the border as part of a national crackdown on illegal logging (Jakarta Post 2005a). ${ }^{19}$

The most vigorous of these timber entrepreneurs were Malaysian citizens. When the news broke in the national media it attracted widespread public condemnation, and the central government was portrayed as incapable of maintaining the nation's territorial sovereignty (Eilenberg 2012b). This contributed to the ongoing territorial disputes between Indonesia and Malaysia that centered on the fact that parts of the land and sea borders were still not properly surveyed and were thus contested by both countries.

These high-profile incidents once again sparked Jakarta's attention to the border problem and, in the following years, under the presidencies of Abdurrahman Wahid (2001) and Megawati Sukarnoputri (2001-2004), a long series of draft laws, surveys and strategy reports on the border issue appeared. These reports discussed possible development and spatial planning initiatives for eradicating illegal cross-border flows. (See Bappenas 2003, 2006a, DIPR 2002, Kepmenhut 2004, Keppres 2003, Perpres 2005b, 2010a). Despite this intensive focus on the border, a main feature of all these reports was a general sense of ambivalence about which government agency or agencies should play the leading role in implementing the many proposed development initiatives. Consequently, no real effort was made to implement these draft laws, and 'illegal' logging along the border remained big business.

\section{Agricultural corridor and security buffer zone}

According to government reports, the only way to guarantee sovereignty, territorial integrity and national security was to improve the welfare of people in the border region (Bappenas 2003). The main strategy for attaining this goal, as noted in several reports, was to create a large agricultural region or corridor along the border (Kawasan Agropolitan) and thereby create local prosperity, reorient the border population's large economic dependence on neighboring Malaysia, and prevent separatism and illegal activities, especially illegal logging (Bappenas 2003, 2004, 2006b). Large-scale oil palm monocropping was highlighted as the primary driver of significant agricultural expansion along the border, which fed into a larger national strategy of development through agrarian expansion. As the global demand for palm oil increases, Indonesia has been allocating large tracts of land for plantations throughout the country and continues to pursue new agricultural frontiers (Ahmad et al. 2009, McCarthy and Cramb 2009, De Koninck et al. 2011). In 2005, Indonesia's palm oil production was 14 million tons, a figure which grew to 23.6 million tons in 2011 and was estimated to reach 25.4 million tons in 2012: a total of 6.35 million hectares - an area the size of England and Wales combined. Indonesia is currently the world's largest producer of crude palm oil and this trade is expanding (FAS 2011).

Following the numerous and vaguely defined border plans previously outlined, and despite the lack of an overall legal framework, in May 2005, Minister of Agriculture Anton Apriantono publicly announced the formation of a 200-kilometer-long plantation corridor which was to span the entire length of the border with Malaysia. The initial goal of this grand plan was to create the world's largest oil palm plantation -1.8 million hectares - in a 5-10 kilometer band along the border (Jakarta Post 2005b). The minister claimed that the plantation would create more than half a million jobs, both locally and

\footnotetext{
$\overline{{ }^{19}}$ The rapid and immense decentralization reforms put into motion in 1999 resulted in a huge number of new laws that were often inconsistent with existing legislation, and district governments often interpreted these new laws very differently from the central government in Jakarta (McCarthy 2004).
} 
through the movement of unemployed surplus workers from densely populated provinces to the sparsely populated border area as part of a large transmigration project. This would secure 'empty' state edges by filling them up with loyal citizens, as a high-ranking military officer told me during a visit in $2005 .^{20}$ The main investors in the plantation project would be the Chinese government and Malaysian companies, investing USD 567 million in projected initial capital over the next five years (Wakker 2006, Potter 2009). ${ }^{21}$ The palm oil would be exported to a growing international market in vegetable oils and turned into biodiesel for domestic consumption.

Ironically, the Indonesian government did not seem to believe that the act of giving land concessions to foreign companies (Malaysian) and opening up for transnational investment (Malaysian and Chinese) along the border would weaken its territorial sovereignty (Hall 2012). More strikingly, many of the Chinese Malaysian entrepreneurs (locally known as tukei's) who had worked the borderland 'illegally' during the previous timber boom now have reoriented their investment into cross-border oil palm plantation development. ${ }^{22}$ Several of these entrepreneurs are still on the provincial police's 'most wanted' list for their previous illegal engagements in the borderland (Eilenberg 2012b). However, in the news media, the government continued to portray Malaysia as a potent threat to its territorial sovereignty - an image that fits well with public national emotions condemning Malaysia as a modern age 'colonizer' (Jakarta Post 2005b). This discrepancy clearly shows how the state discourse of territorial sovereignty and security is used strategically to manipulate and win the hearts and minds of the public and, thus, justify larger military budgets and open new land to state-private investment triggered by Chinese capital, as seen elsewhere in Southeast Asia (Geiger 2008, Barney 2009, Baird 2011, Woods 2011).

Our plan is to develop the areas alongside the border for palm oil plantations, forestry and tourism centers. If we can develop this from the west to the east, security and stability will be better. Palm oil and agricultural cultivation will raise incomes, absorb the workforce and increase regional taxes. Meanwhile, we will be able to keep on nurturing the sense of nationhood and being Indonesian. (President Susilo Yudhoyono, quoted in Tempo 2005)

In a public speech to the provincial government in West Kalimantan during a visit in June 2005 , the president supported the plan of his agricultural minister and said that plantation development was crucial to the overall development of the border area (PKB 2005b). The president (himself a retired army general) expects that plantation development along the Malaysian border will consolidate territorial sovereignty, boost national security and attract international capital and investment. Immediately after the government presented the plan for the oil palm plantation corridor, high-ranking military spokespersons expressed their strong support for the plan. Major General Djoko Sudjono from the Kalimantan

\footnotetext{
${ }^{20}$ Interview with military officer, November 2005 .

${ }^{21}$ During a visit to China in July 2005, the Indonesian President signed an MoU (Memorandum of Understanding) for the construction of Chinese financed infrastructure projects along the border between Indonesia and Malaysia, the first step in the creation of the 1.8-million-hectare oil palm plantation corridor along the border to be reserved for Chinese, Malaysian and national investors. While the Chinese Development Bank would provide capital assistance to the Chinese companies, it was estimated that an additional 40-50 companies would be selected to invest, including the Sinar Mas group in partnership with the Chinese CITIC (China International Trust and Investment Corporation) Group (PTPN 2006).

${ }^{22}$ Interview with district official, November 2012.
} 
Regional Command, for example, expressed the military's views on large-scale plantations in a daily provincial newspaper under the title 'The Army supports oil palm on the border'. He was quoted as saying, 'Why should we [the army] not open up the border area [for oil palm]? The army controls this area. The border area is the sole property of the army' (Pontianak Post 2005).

However, in July 2005, the government-owned plantation cooperative Perkebunan Pusantara (PTPN) informally released a rather hasty and poorly thought-out report showing that the proposed oil palm plantation scheme would run straight through and overlap with several large national parks and hilly areas completely unsuitable for oil palm cultivation (Persero 2005). The extensive planning proposal was quickly turned down by the minister of forestry, who said that his ministry would stop any new conversion of forest into plantations and instead recommended the use of abandoned and deforested land in the border area for such developments (Jakarta Post 2005a). The minister of agriculture later acknowledged that only 180,000 hectares, not 1.8 million hectares, along the border were actually suitable for oil palm plantations (Kompas 2006).

\section{Contestations over land access}

In the months after the release of the PTPN report, the overall plantation plan received much attention from national and worldwide media (The Wall Street Journal 2005, Jakarta Post 2005b). The plan also received much criticism from various national and international NGOs and the Regional Representatives Council (DPD) for its potential impact on the natural and human environment. A major concern of local and international NGOs is that the development of large-scale plantations will prioritize the interests of big business over community-based development. ${ }^{23}$ Such projects, if not carefully implemented, were expected to intensify the conflict over land and resources in the resource-rich area along Indonesia's international border with Malaysia, leading to the further impoverishment of local communities and the destruction of the remaining natural resources (Down to Earth 2005, WWF 2005, Arang 2006). ${ }^{24}$ In particular, the World Wide Fund for Nature (WWF) initiated intensive public relations work against the government because of fears that it would destroy the WWF's 'Heart of Borneo' initiative. Launched in 2004, the WWF initiative seeks to establish a 225,000 square kilometer conservation corridor along the entire Indonesian-Malaysian border (Persoon and Osseweijer 2008).

Among border villagers, the government plantation initiatives were received with skepticism and were widely understood as a part of the central government's efforts to regain control of the border region and especially of the lucrative forestry sector, which it had partly lost with the official implementation of regional autonomy in 1999 (Wollenberg et al. 2006).

We prospered during the logging boom (1999-2005). Of course the tukei's (Malaysian timber barons) took a large share of the profit but we didn't care because everybody received a fair share, even small people like us. We were in control of our own forest and didn't mind them [tukei] smuggling the timber across the border. It was different from the Suharto concessions before regional autonomy; during that time, we received nothing. Now the

\footnotetext{
${ }^{23}$ Interviews with Dayak community heads and environmental NGOs, February-October 2007.

${ }^{24}$ Lesley Potter mention that strong NGO lobbying in local communities has long discouraged investors from expanding plantations into the border area. Securing land is considered too 'complicated' (Potter 2011, 183).
} 
center again wants the major share of the timber profit, we have seen it all before. (Dayak farmer, April 2007)

Although border villagers are not entirely opposed to state development strategies, they do not passively comply with them either. Many are quite favorably disposed toward smallscale plantation development if they can uphold control of their land and engage in cooperation with outside investors. Nevertheless, many fear that locally claimed land along the border is in danger of being forcefully converted into oil palm plantations. ${ }^{25}$ Centuries of kinship relations and labor migration across the border into Sarawak have made local communities aware of the fact that Dayak cousins in Sarawak have experienced a major loss of customary lands as a consequence of state-initiated oil palm development (Colchester et al. 2006, McCarthy and Cramb 2009, Cramb 2011). Consequently, a majority of villagers along the border have a healthy suspicion of large-scale plantation projects.

Local fears of displacement and dispossession are well founded. A presidential regulation of 3 May 2005 stated that the government could force the release of land, when this is in the public interest (Perpres 2005a). This regulation restated the Dutch Agrarian Land Law (Agrarische Wet) from 1870. The 1870 law stipulated that all uncultivated land or wasteland was state property that could be leased out to companies for plantation development on a long-term basis. This law was later, after independence, incorporated into the 1960s Indonesian legislation, enabling the alienation of land in the national interest. While the new Basic Forestry Law (No. 41/1999) released in 1999 recognized (in principle) the existence of local rights to what is considered customary forest land (hutan adat), the legal standing of these rights is still very unclear and largely subject to government interpretations, as there is no clear definition of the term (Moeliono et al. 2009). The Ministry of Forestry must recognize all claims to customary forestland, and ultimately the law states that all forest and forest resources are under state authority (Kepmenhut 2004). The justification of the current development plan for the border area in terms of national interests (national security and development) led to local community fears that the government would apply the 2005 regulations and revoke its newly gained authority over the local forest lands (Suara Bekakak 2006). Most border villagers have no official land certificates and are therefore vulnerable to encroachment from plantation companies backed by military power and state regulations (Borneo Tribune 2008). ${ }^{26}$

Upon receiving much attention and criticism from other countries, the Indonesian government immediately began downplaying and modifying the grand plantation plans. However, the president never publicly denounced the grand plan, and although the initial plan was called off and not implemented in its original form, the Indonesian-Malaysian agricultural corridor along the border was still high on the government agenda (Bappenas 2008, Departemen Pertanian 2009).

\section{Emerging enclosures of customary lands}

A few years after the grand plantation plan had disappeared from the radar screen of national and international media, the first plantation companies entered the borderlands

\footnotetext{
${ }^{25}$ Interviews with Dayak community members, February-October 2007.

${ }^{26}$ Interview with district official, March 2007.
} 
with approval from district governments and supported by regional police and military (Ahmad et al. 2009). For example, during field research in 2007, several subsidiaries ${ }^{27}$ of the Sinar Mas Group, ${ }^{28}$ Indonesia's largest palm oil producer, had begun land surveying in the remote Kapuas Hulu district along the border with Sarawak, and some had already initiated large-scale land clearing and planting. Before initiating the process the companies, accompanied by the regional police, military, and district officials, had invited villagers to 'socialization' meetings, where the villagers were 'persuaded' to allocate their land for oil palm cultivation. Without formal land certificates, most farmers had little chance of resisting such persuasive demands. ${ }^{29}$ The process of acquiring official land certificates is an expensive and complicated affair that requires a well-established network within local government, something few Dayak farmers have. However, since 2006, many district officials and local elites had bought up large parcels of land along the border and had official certificates made - readily awaiting the oil palm boom. ${ }^{30}$

During a 2010 trip to the Kapuas Hulu borderlands, the chief of police in West Kalimantan visited the Sinar Mas subsidiary PT Buana Tunas Sejahtera in Badau. He met with local police and military commanders, community heads, and company personnel and stated that 'Oil palm can open up access to remote areas and help create an investment climate that is conducive to smooth development' ${ }^{31}$ He later encouraged all parties to support the development of oil palm plantations, refrain from acts of vigilantism and resolve any disputes quietly - if not, the law would deal with the culprits (Equator News 2010). ${ }^{32}$

The district government had readily issued plantation licenses for the conversion of about 360,000 hectares of land that was regarded as 'unproductive' wasteland because of decades of the destructive practices of swidden agriculture and rampant illegal logging. Due to poor spatial planning and lack of clear regulations, these plantation concessions overlapped with local traditional lands, resulting in company-community conflicts. ${ }^{33}$ Several company survey teams even entered protected forests set aside for conservation purposes (Kompas 2011a). ${ }^{34}$

Although Kapuas Hulu is the most forested district in the province, it is also the district with the least economic growth, which according to the government is a result of its underdeveloped agricultural sector and backward population. ${ }^{35}$ Until recently, the district was heavily dependent on its forestry sector, but a central government logging ban has now severely crippled this sector. Therefore, the district government enthusiastically supports any kind of plantation project that will bring much-needed local revenue. In the initial phase of construction and planting, local villagers were hired by the plantation companies on a daily basis, but they were soon replaced by imported migrant workers from the island

\footnotetext{
${ }^{27}$ PT Buana Tunas Sejahtera, PT Sentra Karya Manunggal, PT Khatuliustiwa Agra Abadi, PT Kapuas Indo Palm Industri, PT Sawit Kencana Kapuas and PT Citra Nusa Indonesia. Each company has a 20,000-hectare license (interview with district official, July 2007).

${ }^{28}$ In the 2005 plan for the grand border plantation, the Sinar Mas Group was highlighted as a key player that could attract the required Chinese investment capital (Wakker 2006).

${ }^{29}$ Interview with Dayak community member, August 2007.

${ }^{30}$ Interview, district assembly member, March 2007.

${ }^{31}$ Interview with Dayak community head, February 2011.

${ }^{32}$ Interview with Dayak community head, February 2011.

${ }^{33}$ Interviews with Dayak community members, January-June 2011.

${ }^{34}$ Interview with district official, June 2007.

${ }^{35}$ A majority of the Dayak communities inhabiting the border hills still reside in longhouse settlements and practice swidden agriculture, practices considered archaic and anti-development by government and private companies (Ahmad et al. 2009).
} 
of Flores (who could be easily disciplined), housed in newly erected settlements within the plantation compounds. By 2011, large patches of land along the border in Kapuas Hulu were under oil palm cultivation; the first crop was ready to be harvested in $2012 .{ }^{36}$ Furthermore, in 2012, the subsidiary of Sinar Mas, PT Smart, initiated the construction of a large palm oil refinery in the border town of Nanga Badau in order to export the crude palm oil directly across the border to Malaysia: an additional six refineries are planned in the district (Equator News 2012).

It is significant that government, military and plantation companies readily justify the enclosure of customary lands for large-scale plantation development by drawing on the discourse of national sovereignty. They stress the national security advantages of an ordered landscape of monocrop plantations and accompanying infrastructure along the border. The latest chapter in an ongoing controversy concerning the disappearance of border poles has recently sharpened the focus on border militarization and national sovereignty. With headlines like 'Malaysia violates Kalimantan border', Indonesian news media and military spokespersons have occasionally accused Malaysian plantation companies of moving border poles several meters into Indonesian territory in order to gain access to more land and timber (Tempo 2011). The Indonesian military even claims that 50 poles have gone missing altogether. For example, in 2009 and again in 2011, the military command in Pontianak destroyed several Malaysian oil palm plots on the border that were said to 'illegally' encroach on Indonesian territory (Jakarta Post 2009, Kompas 2011b). Ironically, the provincial government has directly encouraged Sarawak companies to invest in the West Kalimantan border region (The Star 2010), and it was recently estimated that about 70 percent of oil palm companies in the province are already Malaysian majority owned (Colchester 2011). Although foreign companies are not allowed to formally own land in Indonesia, this is easily sidestepped by colluding with local Indonesian companies.

Critics observe that the military focus on the discourses of national sovereignty and security is manufactured in order to justify larger military budgets. Several commentators claim that the military build-up in the border area is more about reclaiming a share of the revenues lost after the fall of Suharto from further timber harvesting and oil palm plantations than dealing with illegal activities threatening national security (WALHI 2007). It could be argued that the military needs a 'good cause' to prove the continued need for a strong military establishment in post-Suharto Indonesia. For example, the Indonesian military has recently begun calling for increased funds to provide sufficient border patrols and create new border posts and military checkpoints (Jakarta Globe 2010a). However, according to the military, its role is not only to defend the country against outside aggression; it also believes itself to have an educational role. Military personnel stationed on the border have recently become teaching assistants in rural schools, where they teach 'lessons in nationalism' in order to implement a 'sense of nationalism' among the 'autonomous tribal communities' (Antara 2012). ${ }^{37}$

These initiatives feed into the TMMD program - an acronym for the 'Indonesian National Armed Forces United in Village Development'. In the district of Kapuas Hulu, the TMMD program was introduced by the military in 2010, and its main rationale was to improve 'backward villages' along the border and maintain a sense of national unity, which involved instructions in 'village defense' and 'mental development' (appropriate lifestyle, family planning, religious guidance and nationalism) supplemented with the

\footnotetext{
${ }^{36}$ Interviews with plantation workers and field observations, January-June 2011.

${ }^{37}$ Interviews with Dayak community members and district military personel, January-June 2011.
} 
construction of physical infrastructure like roads, bridges and schools. ${ }^{38}$ A military lieutenant from the regional command brusquely announced in national media, 'It is all about protecting the Unitary State of the Indonesian Republic (NKRI) or death!' (Equator News 2011). In other words, the military will defend state unity by force if necessary: a remnant discourse of the Suharto era's militarized nationalism.

The senior segment of the border population interviewed in 2011 views the TMMD program with caution and mixed emotions. The program conjures memories of forced labor, indoctrination and resettlement during the 1970s-1980s counter-insurgency programs (see Davidson 2003, Peluso 2008, Eilenberg 2011). ${ }^{39}$ In the 1980s, the Suharto government introduced an official program of direct military development intervention called AMD (Indonesian Armed Forces Enter the Village). In the border area, the AMD programs involved military personnel, who were involved in teaching projects and the development of rice production schemes. Although development was the official rhetoric of the AMD programs, they were primarily an attempt to take control of the region's immense natural resources and to prevent 'unreliable' border communities from being influenced by foreign (communist) ideologies (Eilenberg 2011). The processes of militarization that have taken place in the West Kalimantan borderlands in many ways resemble what Kevin Woods in his recent study of the China-Burma borderlands has called 'military territorialization' (i.e. 'military-state agencies and officers exhibiting power and authority over land and populations ...') (Woods 2011, 748). However, compared to the case of Burma, the Indonesian military actors' economic incitements and cooperation with private capital along the border are less conspicuous. They mostly work behind the scenes and receive 'fees' by lending out personnel as plantation guards and keeping up steady pressure on local communities to conform to plantation company demands. ${ }^{40}$

The military presence and authority in the border area have waxed and waned over time, from being extremely conspicuous during the Suharto era to being less noticeable since the decentralization reforms in 1999 (Mietzner 2009). The political role of the military was greatly reduced after the fall of Suharto, as the new reform governments initiated a restructuring of the institution. Although it has lost ground in civil politics, the military has largely maintained its role in the business sector (Human Right Watch 2006).

\section{Transmigration - resettling the Indonesian borderlands}

As mentioned in the initial 2005 grand plantation plan, the main labor resource catering to the proposed plantation corridor along the border was outside migrant workers, who needed to be permanently settled along the border as part of high-profile government-initiated transmigration schemes - disturbingly similar to the failed Suharto era transmigration schemes found elsewhere in Kalimantan. ${ }^{41}$

Populating the unruly borderlands with resettled loyal (Javanese) citizens and promoting agricultural development was not a novel idea. The Indonesian military and the Ministry of Transmigration had nurtured it since the late 1960s (Mitoyat et al. 1978, Marr 1990).

\footnotetext{
${ }^{38}$ Interviews with District military personnel, March 2011.

${ }^{39}$ Interview with Dayak customary head, May 2011.

${ }^{40}$ Interviews with Dayak community members, January-June 2011.

${ }^{41}$ The Dutch colonial government first introduced transmigration from densely populated islands like Java to low-density areas in order to provide a reliable workforce for their plantation schemes in the outer islands like Sumatra. It has been applied in a similar way by successive Indonesian administrations ever since (Hardjono 1988).
} 
Southeast Asia as a whole has a long history of frontier colonization through population resettlement (De Koninck and Déry 1997, De Koninck 2006, Baird and Shoemaker 2007, Peluso and Vandergeest 2011, Grundy-War and Wong 2002).

After the Indonesian military anti-communist insurgency along the Kalimantan-Sarawak border in the mid-1970s and the 1980s, 'retired' military personnel from Java and Sumatra who had served in the area were persuaded to settle in the borderlands. Jamie Davidson and Douglas Kammen explain how plans were put forward in the mid-1970s to settle about 1300 military families named 'transmigrant battalions' in the West Kalimantan borderland each year (Davidson and Kammen 2002, 79). ${ }^{42}$ At the time, though, only a few settled there permanently, and because they were few in number, they did not have the expected 'civilizing effect' on the borderland population (Eilenberg 2011). ${ }^{43}$ Today, there is considerable local concern, however, that the new increase in military personnel (and their families) and foreign plantation workers along the border will tip the population distribution and make the ethnic border population a minority in their own region. ${ }^{44}$

Since the logging stop in 2005, the military have made many new camps along the border. In Putussibau a whole military battalion have been stationed. We are only few and live far apart, we are quickly being outnumbered. For now we are the majority and can make decisions on local matters, but that can quickly change. (Dayak community head, March 2007)

Not until 2006, when the interest of private capital in the borderlands was awakened, did the minister of manpower and transmigration announce a more specific plan of reinstating the border transmigration program of the $1980 \mathrm{~s} .{ }^{45} \mathrm{He}$ introduced the concept of 'Integrated Autonomous Towns' (KTM), which, compared to the poorly constructed transmigration settlements of the past, would be fully equipped with electricity, transportation and communication infrastructure. ${ }^{46}$ He further envisaged that the military should once again act as 'pioneers' by settling in the borderlands, taking the first steps in erecting the KTMs, and creating the infrastructure for a later wave of 'foreign' Javanese migrants' (BBC 2006, Antara 2007). According to the minister, each of the proposed KTM constructions was expected to be inhabited by 10,000 families, comprising about 40,000 people (Antara 2009). ${ }^{47}$ Coincidentally, in 2010, the transmigration program received a USD 1.11 billion capital infusion from the private business sector, primarily plantation companies looking for a reliable workforce for their investments in plantation developments along the border (Jakarta Globe 2010b).

In cooperation with the National Agency for Border Management, 12 KTMs are currently being constructed in the borderlands of Papua, East, Central ${ }^{48}$ and West Kalimantan, and according to the agency they will make up the country's new territorial 'security belt'

\footnotetext{
${ }^{42}$ Simultaneously with the incursion of military 'transmigration battalions', more than 70,000 rural Chinese Hakkas occupying stretches of the West Kalimantan borderlands were accused of being communist sympathisers and forcefully resettled away from the border (Soemadi 1974). Similar resettlements of Chinese Hakkas took place on the Malaysian side of the border (Yong 2006).

${ }^{43}$ Interviews with retired military personnel settled on the border, February-October 2007.

${ }^{44}$ Interviews with Dayak community members, February-October 2007.

${ }^{45}$ In the previous year, 2005, a research unit from the Ministry of Manpower and Transmigration published a book on a development model for transmigration in the border regions accentuating national security and plantation development (see for example Puslitbangtrans 2005).

${ }^{46} \mathrm{KTM}=$ Kota Terpadu Mandiri.

${ }^{47}$ In 2012, the first 361 families were settled along the West Kalimantan border as part of the transmigration program (Kemenakertrans 2012).

${ }^{48}$ For a discussion of the KTM transmigration schemes in Central Kalimantan see Potter (2012).
} 
(Kemenakertrans 2011a, 2011b). ${ }^{49}$ As the minister of manpower and transmigration tried to assure the provincial officials during a November 2011 workshop on border resettlement in the provincial capital of West Kalimantan, 'the transmigration program will solve the border problem and open up this isolated region', and, he continued, 'It would be impossible to develop the border without involving resettlement' (Borneo Tribune 2011). He was further quoted as saying that 'the border region is important, because of its economic value, geopolitics security and defense. Moreover, it has a strategic position as a fence and front porch of the country' (Haluan Kepri 2011).

The minister emphasized that the main obstacle to developing and 'securing' the country's borders and managing the region's abundant natural resources was the low population density. The limited availability of a reliable labor force would, according to the minister, discourage private business investment. As stated by the minister to the national news agency, Antara: 'The major problem is the limited availability of labor and capital to support the management of the natural resource potential. The level of population density in the border region is generally very low with an uneven distribution' (Antara 2011).

Local indigenous communities were readily seen as an unreliable workforce and difficult to 'discipline' (Kemenakertrans 2011a). The minister was echoing both the Indonesian Ministry of Agriculture and the Indonesian Oil Palm Growers Association (Apkasindo) (Media Perkebunan 2011). The Secretary General of Apkasindo, Asmar Arsjad, promptly played the security card and urged the government to open up the borderlands for transmigration and plantations in order to prevent the region from being annexed by Malaysia. He proclaimed that about 500,000 hectares of land along the almost 2000-kilometer-long border would be suitable for plantations and that the resettled Javanese 'surplus' farmers, besides working the plantations, could serve as border guards (Bisnis Indonesia 2011). Similar processes are taking place in other resource-rich Indonesian borderlands, such as the Merauke region along the Papua-Papua-New-Guinea border, where millions of hectares of land are being cleared for plantation development and transmigration settlements, justified through similar discourses of territorial sovereignty and national unity along a thinly populated resource frontier (Ginting and Pye 2011). ${ }^{50}$

In 2007 when the (oil palm) companies first entered our village territory we were promised compensation, better roads and jobs in the plantations, but we were only hired as day laborers in the planting phase. The companies 'convinced' several community heads to sell more and more community land and afterwards they brought in outside workers from Flores and Java who accepted starving salaries. They said that we were difficult people to work with. Oil Palm plantations are new to the area, before we just had [jungle] rubber. We know little about [cultivating] oil palms everything happened so quickly. I am afraid that it will end in violent conflict as happened in the districts down river a few years back. (Dayak farmer, March 2011)

Taking the historical heredity of the highly contested Indonesian transmigration programs into consideration, this more recent attempt to reinstate large-scale population resettlements on the

\footnotetext{
${ }^{49}$ The district of Kapuas Hulu is one of three pilot sites in West Kalimantan of 10,000 hectares each already gazetted for the KTM (interviews with district officials, October 2011).

${ }^{50}$ Examples of recent mega-schemes along the West Papua border include the Merauke Integrated Food and Energy Estate (MIFEE) (Ito et al. 2011). Furthermore, military transmigration schemes have a long history in the West Papua borderland as part of military 'territorial management'. The schemes involve both retired and active members of the armed forces and their families. They are buffer settlements, used to quell West Papuan separatist movements and their access across the border (Budiardjo 1986).
} 
border may turn out to be a Pandora's box of potential conflict - not least because government and military rhetoric of development and security closely resembles that of the Suharto era and appears to be implemented in a similar fashion. Taking a critical view, it is argued that current Indonesian development programs are in danger of repeating history and turning into more failed grand schemes. The frontier tropes of 'unutilized' lands and 'backward' populations are still readily applied in government rhetoric, conjuring up past images of displacement and dispossession. Although the current 'reformed' transmigration program, in the form of KTMs, has been said to be much improved compared to the programs of the past, and better integrated in regional settings, contested issues of land rights and resource access and compensation are still unsolved in the border region. Furthermore, the overlapping and opaque agendas of government agencies and large-scale private capital in the Kalimantan borderlands make it difficult for local populations to assess the concrete development benefits besides low-paid jobs in a growing plantation economy and loss of customary lands.

\section{Conclusions}

In this study, I have discussed how the rapid agrarian transformations currently taking place in the Indonesian borderlands, with palm oil as the boom crop, involve a complex interplay of forces. These forces range from global demands for crude palm oil for biodiesel and vegetable oils to discourses about territorial sovereignty and regional attempts to promote plantation development as the main economic savior and revenue provider in impoverished border regions. Through extensive development plans that involve allocating private land concessions and increasing military authority, the Indonesian government has once again accentuated the perceived importance of strengthening state presence and sovereignty along its borders with Malaysia. It is envisaged that the 'uncivilized' and 'unruly' border region once again should be controlled by a strong army presence, and plantation 'development' should be the new 'safety net' and buffer zone against an expanding Malaysian neighbor. The case of the Indonesian-Malaysian border reveals that powerful discourses of security and territorial sovereignty play a major role in state-led processes of land colonization, legitimizing resettlement and dispossession. However, the case also reveals the flipside of the imagined 'sovereign state' when, for example, the national military publically condemns Malaysian intrusions into Indonesian territory and simultaneously serves as security for Malaysian extractive companies along the border. It clearly illustrates the fragmented character of the state and, as suggested by Barker and Van Klinken (2009), 'institutional patchiness' might be a more accurate term in describing the institutional arrangement of the modern Indonesian state. Uneasy relationships and contradictory ties and commitments among state authorities coexist at various levels of government and in various departments, and especially the Indonesia military have, since independence, played a powerful role in both national politics and private business.

Today, the militarist rhetoric of the former Suharto regime is echoed in terms like 'security buffer zones' and 'security belts', while population resettlements and agricultural expansion along Indonesia's territorial borders are widely used and often evoke past failures. Hence, one major consequence of the renewed interest of the Indonesian government and private capital in the border region might be a new era of top-down development. One may speculate that these large-scale attempts at domesticating the border region could lead to progressive growth of central state authority in the borderlands, with large-scale actors like the military once again becoming major players in colonizing the borderlands and extracting their natural resources. The remilitarization of the borderlands could thus indicate the beginning of another chapter in the waxing and waning of military power on the border. 
Moving away from its role of protector of internal unity by quelling internal separatist movements during Suharto's New Order regime, the military now wants the lucrative role of protector of national sovereignty, working in tandem with private transnational capital.

Returning to the case of the world's largest oil palm plantation and its consequent failure to materialize in the envisioned form, we can see how grand schemes are often undermined by the numerous and, at times, contradictory agendas of various state agents and agencies. This is a vivid example of frontier imagery with its utopian promises of 'unoccupied' lands, unlimited economic advancement and instant riches. The frontier then becomes a kind of 'tabula rasa', a blank page on which the implementation of developmental agendas can be written or from which resources can be extracted (McCarthy and Cramb 2009, 113). As documented by several studies, large-scale government interference and top-down development plans have in the past been contested and met with violence from rural communities in the Indonesian uplands and elsewhere in Southeast Asia (Li 2007, Caouette and Turner 2009, Peluso 2009). The rapid closure of the resource 'frontier' along the West Kalimantan border has resulted in increased local conflicts in the last decade and has intensified the scramble for natural resources and 'free' land. Thus, if largescale agrarian expansion and transmigration schemes are not adjusted to local conditions, there is a potential danger of heightened tension over access to land and control of the remaining natural resources in the West Kalimantan borderlands, as witnessed in its most violent form in other parts of Kalimantan (Davidson 2003, Peluso 2008).

\section{References}

Ahmad, Nurhanudin, W. Wagiman and T. Bawor. 2009. Pembangunan Perkebunan Sawit Di Perbatasan Indonesia-Malaysia: Diskriminasi Rasial Terhadap Masyarakat Adat. Bogor: Tim Advokasi Sawit Perbatasan.

Agamben, G. 2005. State of exception. Chicago: University of Chicago Press.

Antara. 2007. Minister: Military can act as transmigration pioneers in border Areas. Antara News Agency, 23 Feb.

Antara. 2009. Government to build 30 self-suporting integrated towns in border areas. Antara News Agency, 5 Aug.

Antara. 2011. 12 Kota Transmigrasi Akan Dibangun Di Perbatasan, Antara News Agency, 29 Now.

Antara. 2012. Personel Tni Di Perbatasan Jadi Guru Bantu. Antara News Agency, 25 Jan.

Arang, L. 2006. Kelapa Sawit Sang Primadona: Suatu Analysis Pembangunan Perkebunan Kelapa Sawit Di Kabupaten Wilayah Perbatasan Indonesia-Malaysia, Provinsi Kalimantan Barat. WWF Indonesia, Forest Conversion Initiative Program.

Aspinall, E. and G. Fealy. 2003. Local power and politics in Indonesia: Decentralization and democratization. Singapore: Institute of Southeast Asian Studies.

Baird, I. and B. Shoemaker. 2007. Unsettling experiences: Internal resettlement and international aid agencies in Laos. Development and Change, 38(5), 437-461.

Baird, I. 2011. Turning land into capital, turning people into labor: Primitive accumulation and the arrival of large-scale economic land concessions in the Lao people's democratic republic. New Proposals: Journal of Marxism and Interdisciplinary Inquiry, 5(1), 10-26.

Bappenas. 2003. Strategi Dan Model Pengembangan Wilayah Perbatasan Kalimantan. Jakarta: Kementerian Perencanaan Pembangunan Nasional, Badan Perencanaan Pembangunan Nasional.

Bappenas. 2004. Kawasan Perbatasan: Kebijakan Dan Strategi Nasional Pengelolaan Kawasan Perbatasan Antarnegara Di Indonesia. Jakarta: Kementerian Perencanaan Pembangunan Nasional, Badan Perencanaan Pembangunan Nasional.

Bappenas. 2006a. Buku Utama Rencana Induk Pengelolaan Perbatasan Negara. Jakarta: Kementerian Perencanaan Pembangunan Nasional, Badan Perencanaan Pembangunan Nasional.

Bappenas. 2006b. Rencana Induk Pengelolaan Perbatasan Negara: Buku Rinci Di Provinsi Kalimantan Barat (Draft Akhir). Jakarta: Kementerian Perencanaan Pembangunan Nasional, Badan Perencanaan Pembangunan Nasional. 
Bappenas. 2008. Bahan Diskusi: Rencana Pembangunan Jangka Menengah Pengembangan Kawasan Perbatasan Tahun 2010-2014. Jakarta: Kementerian Perencanaan Pembangunan Nasional, Badan Perencanaan Pembangunan Nasional.

Bappenas. 2011. Profil Wilayah Perbatasan Negara Di Provinci Kalimantan Barat. Jakarta: Kementerian Perencanaan Pembangunan Nasional, Badan Perencanaan Pembangunan Nasional.

Barker, J. and G. van Klinken. 2009. Reflections on the state in Indonesia. In: Gerry van Klinken and Joshua Barker, eds. State of authority: The state in society in Indonesia. Ithaca, NY: Southeast Asia Program, Cornell University, pp. 17-46.

Barney, K. 2009. Laos and the making of a 'relational' resource frontier. Geographical Journal, $175(2), 146-159$.

Baud, M. and W. van Schendel. 1997. Toward a comparative history of borderlands. Journal of World History, 8(2), 211-242.

BBC. 2006. Indonesia's transmigration programme aimed at border areas. BBCV Monitoring International Report, 13 Mar.

Bisnis Indonesia. 2011. Pemerintah Didesak Buka Perkebunan Sawit Untuk Jaga Perbatasan. Bisnis Indonesia, 16 Oct.

BNPP. 2011. Desain Besar Pengelolaan Batas Wilayah Negara Dan Kawasan Perbatasan Tahun 2011-2025. Jakarta: Kementerian Perencanaan Pembangunan Nasional, Badan Nasional Pengelola Perbatasan.

Borneo Tribune. 2008. Tanah Di Perbatasan Belum Bersertifikat. Borneo Tribune, 25 Sep.

Borneo Tribune. 2011. Transmigrasi Masuk Perbatasan. Borneo Tribune, 29 Nov.

Borras, S.M. and J.C. Franco. 2011. Political dynamics of land-grabbing in Southeast Asia: Understanding Europe's role. Amsterdam: The Transnational Institute.

Brown, D.W. 1999. Addicted to rent: Corporate and spatial distribution of forest resources in Indonesia; Implications for forest sustainability and government policy. Jakarta: Indonesia UK Tropical Forestry Mangement Programme.

Budiardjo, C. 1986. The politics of transmigration. The Ecologist, 16(2/3), 111-116.

Caouette, D. and S. Turner. 2009. Agrarian angst and rural resistance in contemporary Southeast Asia. London: Routledge.

Colchester, M. 2011. Palm oil and indigenous peoples in South East Asia. Rome: International Land Coalition (ILC).

Colchester, M., N. Jiwan, Andiko, M. Sirait, A.Y. Firdaus, A. Surambo and H. Pane. 2006. Promised land - Palm Oil and land acquisition in Indonesia. Implications for local communities and indigenous peoples. Forest People Programme and Perkumpulan Sawit Watch.

Cramb, R.A. 2011. Agrarian transitions in Sarawak: Intensification and expansion reconsidered. In: R. D. Koninck, S. Bernard and J.-F. Bissonnette, eds. Borneo transformed: Agricultural expansion on the Southeast Asian Frontier. Singapore: NUS Press, pp. 44-93.

Crouch, H. 2007. The army and politics in Indonesia. Jakarta: Equinox Publishing.

Davidson, J.S. 2003. The politics of violence on the Indonesian periphery. South East Asia Research, $11(1), 59-89$.

Davidson, J.S. and D. Kammen. 2002. Indonesia's unknown war and the lineages of violence in West Kalimantan, Indonesia. Indonesia, 73(April), 53-87.

De Koninck, R. 2006. On the geopolitics of land colonization: Order and disorder on the Frontiers of Vietnam and Indonesia. Moussons, 9(10), 33-59.

De Koninck, R. and S. Déry. 1997. Agricultural expansion as a tool of population redistribution in Southeast Asia. Journal of Southeast Asian Studies, 28(1), 1-26.

De Koninck, R. et al. 2011. Borneo transformed: Agricultural expansion on the Southeast Asian Frontier. Singapore: NUS Press.

Dennis, P. and J. Grey. 1996. Emergency and confrontation: Australian military operations in Malaya and Borneo 1950-1966. St Leonards: Allen \& Unwin.

Departemen Pertanian. 2009. Pedoman Teknis Pengendalian Lahan Pertanian Di Wilayah Perbatasan. Jakarta: Direktorat Pengelolaan Lahan, Diirektorat Jenderal Pengelolaan Lahan Dan Air, Departemen Pertanian.

DIPR. 2002. Strategi Dan Konsepsi Pengembangan Kawasan Perbatasan Negara, Bahan Rapat Kebijakan Dan Program Pengembangan Dan Pengelolaan Wilayah Perbatasan. Departemen Permukiman Dan Prasarana Wilayah Direktorat Jenderal Penataan Ruang (DIPR).

Donnan, H. and T.M. Wilson. 1994. Border approaches: Anthropological perspectives on frontiers. Lanham: University Press of America. 
Down to Earth. 2005. Oil Palm Expansion Will Bring More Conflict. Down to Earth, 66.

Eilenberg, M. 2009. Negotiating autonomy at the margins of the state: The dynamics of elite politics in the Borderland of West Kalimantan, Indonesia. South East Asia Research, 17(2), 201-227.

Eilenberg, M. 2011. Straddling the border: A marginal history of Guerrilla warfare and 'counter-insurgency' in the Indonesian Borderlands. Modern Asian Studies, 45(6), 1423-1463.

Eilenberg, M. 2012a. At the edges of states: Dynamics of state formation in the Indonesian Borderlands. Leiden: KITLV Press.

Eilenberg, M. 2012b. The confession of a timber Baron: Patterns of patronage on the IndonesianMalaysian border. Identities: Global Studies in Culture and Power, 19(2), 149-167.

Eilenberg, M. and R.L. Wadley. 2009. Borderland livelihood strategies: The socio-economic significance of ethnicity in cross-border labour migration, West Kalimantan, Indonesia. Asia Pacific Viewpoint, 50(1), 58-73.

Equator News. 2010. Kapolda Kunjungi Pt Buana Tunas Sejahtera. Equator News, 28 Jan.

Equator News. 2011. Tmmd Bagian Solusi Pertahankan Nkri. Equator News, 4 Jun.

Equator News. 2012. PT Smart Tbk Bangun Pabrik CPO. Equator News, 25 Jan.

FAS. 2011. Indonesia oilseeds and products annual report 2011. Washington, D.C.: United States Department of Agriculture, Foreign Agricultural Service.

Fold, N. and P. Hirsch. 2009. Re-thinking frontiers in Southeast Asia: Editorial. The Geographical Journal, 175(2), 95-97.

Geiger, D. 2008. Frontier encounters: Indigenous communities and settlers in Asia and Latin America. Copenhagen: IWGIA.

Ginting, L. and O. Pye. 2011. Resisting agribusiness development: The merauke integrated food and energy estate in West Papua, Indonesia. Paper presented at the International Conference on Globasl Land Grabbing. Land Deals Politics Initiative (LDPI), University of Sussex.

Grundy-War, C. and E. Wong. 2002. Geographies of displacement: The Karenni and the Ahan across the Myanmar-Thailand border. Singapore Journal of Tropical Geography, 23(1), 93-122.

Hagmann, T. and B. Korf. 2012. Agamben in the Ogaden: Violence and Sovereignty in the EthiopianSomali Frontier. Political Geography, 31(4), 205-214.

Hall, D. 2011. Land grabs, land control, and Southeast Asian crop booms. Journal of Peasant Studies, $38(4), 837-857$.

Hall, D. 2012. Land. Cambridge: Polity Press.

Haller, D. and H. Donnan. 2000. Borders and borderlands: An anthropological perspective. Journal of European Ethnology, 30(2).

Haluan Kepri. 2011. Transmigrasi Di Perbatasan Dikembangkan. Haluan Kepri, 14 Dec.

Hamid, M.S.H. and T. Widianto. 2001. Kawasan Perbatasan Kalimantan: Permasalahan Dan Konsep Pengembangan. Jakarta: Pusat Pengkajian Kebijakan Teknologi Pengembangan Wilayah - BPPT.

Hansen, T.B. and F. Stepputat. 2006. Sovereignity revisited. Annual Review of Anthropology, 35(1), 295-315.

Hardjono, J. 1988. The Indonesian transmigration program in historical perspective. International Migration, 26(4), 427-439.

Harwell, E. 2000. The un-natural history of culture: Ethnicity, tradition and territorial conflict in West Kalimantan, Indonesia, 1800-1997. Thesis (PhD). Yale University.

Hirsch, P. 2009. Revisiting frontiers as transitional spaces in Thailand. Geographical Journal, 175(2), 124-132.

Human Rights Watch. 2006. Too high a price: The human rights cost of indonesian military's economic activities. Human Right Watch, $18(5$ (C)).

Ishikawa, N. 2010. Between frontiers: Nation and identity in a Southeast Asian Borderland. Ohio: Ohio University Press.

Ito, T., N.F. Rachman and A.L. Savitri. 2011. Naturalizing Land Dispossession: A Policy Discourse Analysis of the Merauke Integrated Food and Energy Estate. Paper presented at the International Conference on Globasl Land Grabbing. Land Deals Politics Initiative (LDPI), University of Sussex.

Jakarta Globe. 2010a. Military to boost presence in Papua, Kalimantan border zones this year. Jakarta Globe, 30 Mar.

Jakarta Globe. 2010b. Private sector invests Rp 10 Trillion in Indonesia's transmigration program. Jakarta Globe, 11 Feb.

Jakarta Post. 2005a. Forest Conversion on Kalimantan Border Halted. Jakarta Post, 12 Sep. 
Jakarta Post. 2005b. Government plans world's largest oil palm plantation. Jakarta Post, 18 Jun.

Jakarta Post. 2009. Malaysia moves border poles into Ri's land for oil palm plantations. Jakarta Post, 4 Mar.

Jakarta Post. 2010. New military command in Kalimantan to guard border areas. Jakarta Post, 31 Jan.

Jakarta Post. 2011a. Government Boosts Border Budget 2,000\%. Jakarta Post, 22 Oct.

Jakarta Post. 2011b. Government to develop border areas before 2014. Jakarta Post, 27 Dec.

Jakarta Post. 2012. Study Says Military Complicit in Illegal Logging. Jakarta Post, 27 Feb.

Jones, M. 2002. Conflict and confrontation in South East Asia, 1961-1965. Cambridge: Cambridge University Press.

Jones, R. 2009. Sovereignity and statelessness in the border enclaves of India and Bangladesh. Political Geography, 28, 373-381.

Kemenakertrans. 2011a. Kemenakertrans Akan Bangun 35 KTM Baru Di Kawasan Transmigrasi. Jakarta: Kementerian Tenaga Kerja dan Transmigrasi.

Kemenakertrans. 2011b. Presiden Sby Dukung Pembangunan Ktm Di Kawasan Perbatasan Ri. Jakarta: Kementerian Tenaga Kerja dan Transmigrasi.

Kemenakertrans. 2012. Program Penyiapan Permukiman Dan Penempatan Transmigrasi Baru Wilayah Perbatasan Tahun 2012. Jakarta: Kementerian Tenaga Kerja dan Transmigrasi.

Kepmenhut. 1999. Tentang penunjukan Perum Perhutani untuk mengelola kawasan hutan sebelumnya berada di bawah konsesi PT. Jamaker di Provinsi Kalimantan Barat dan Provinsi Kalimantan Timur. Jakarta: Keputusan Minteri Kehutanan dan Perkebunan, No. 376.

Kepmenhut. 2004. Rencana Stratejik Pengelolaan Kawasan Hutan Wilayah Perbatasan Ri-Malaysia Di Kalimantan. Jakarta: Keputusan Menteri Kehutanan, No. SK.55.

Kep/P.Y/X 1980. Surat Keterangan, Dewan Pengerus Yayasan Maju Kerja, Jakarta, No. 165.

Keppres. 1994. Badan Pengendali Pembangunan Kawasan Perbatasan. Jakarta: Keputusan Presiden Republik Indonesia, No. 44.

Keppres. 1999. Cabutan Keputusan Presiden Nomor 44 Tahun 1994 Tentang Badan Pengendali Pelaksanaan Pembangunan Wilayah Perbatasan Di Kalimantan. Jakarta: Keputusan Presiden Republik Indonesia, No. 63.

Keppres. 2003. Penataan Ruang Kawasan Perbatasan Kalimantan, Sarawak Dan Sabah. Keputusan President Republik Indonesia, Draft Ke-7, Direktorat Jenderal Penataan Ruang.

KNPDT. 2007. Rencana Aksi Nasional Pembangunan Daerah Tertinggal Tahun 2007-2009. Jakarta: Kementerian Negara Pembangunan Daerah Tertinggal.

Kompas. 2006. Deptan Hanya Izinkan 180.000 Hektar Di Perbatasan. Kompas, 6 May.

Kompas. 2011a. Masyarakat Adat Tolak Sawit. Kompas, 12 Sep.

Kompas. 2011b. Perusahaan Sawit Malaysia Serobot Tanah Perbatasan Indonesia. Kompas, 8 Nov.

Laungaramsri, P. 2012. Frontier capitalism and the expansion of rubber plantations in Southern Laos. Journal of Southeast Asian Studies, 43(3), 463-477.

Li, T.M. 2007. The will to improve: Governmentality, development and the practice of politics. Durham and London: Duke University Press.

Li, T.M. 2011. Centering labor in the land grab debate. Journal of Peasent Studies, 38(2), 281-298.

Lund, C. 2011. Fragmented sovereignty: Land reform and dispossession in Laos. Journal of Peasant Studies, 38(4), 885-905.

Marr, C. 1990. Uproting people, destroying cultures. The Multinational Monitor, 11(10). Available at: http://www.multinationalmonitor.org/hyper/issues/1990/10/index.html

McCarthy, J.F. 2004. Changing to Gray: Decentralization and the emergence of volatile socio-legal configurations in Central Kalimantan, Indonesia. World Development, 32(7), 1199-1223.

McCarthy, J.F. and R.A. Cramb. 2009. Policy narratives, landholder engagement, and oil palm expansion on the Malaysian and Indonesian frontiers. Geographical Journal, 175(2), 112-123.

Media Perkebunan. 2011. Sawit Solusi Mensejahterakan Daerah Perbatasan. Media Perkebunan, 20 Nov.

Mietzner, M. 2009. Military politics, Islam, and the state in Indonesia: From turbulent transition to democratic consolidation. Singapore: Institute of Southeast Asian Studies.

Migdal, J.S. 2004. Mental maps and virtual checkpoints: Struggles to construct and maintain state and social boundaries. In: J.S. Migdal, ed. Boundaries and belonging: States and societies in struggle to shape identities and local practices. Cambridge: Cambridge University Press, pp. 3-26.

Mitoyat, R.E., D. Mulyanto and P. Yudono. 1978. Laporan Survai Transmigrasi Daerah Perbatasan Propinsi Kalimantan Barat Bidang Perencanaan Pertanian. Jakarta: Departemen Tenaga Kerja, Transmigrasi dan Koperasi. 
Moeliono, M., E. Wollenberg and G. Limberg. 2009. The decentralization of forest governance: Politics, economics and the fight for control of forest in Indonesian Borneo. London: Earthscan.

Obidzinski, K., A. Andrianto and C. Wijaya. 2007. Cross-border timber trade in Indonesia: Critical or overstated problem? forest governance lessons from Kalimantan. International Forestry Review, $9(1), 526-535$.

Peluso, N.L. 1992. Rich forests, poor people: Resource control and resistance in Java. Berkeley: University of California Press.

Peluso, N.L. 2008. A political ecology of violence and territory in West Kalimantan. Asia Pacific Viewpoint, 49(1), 48-67.

Peluso, N.L. 2009. Rubber erasures, rubber producing rights: Making racialized territories in West Kalimantan, Indonesia. Development and Change, 40(1), 47-80.

Peluso, N.L. and P. Vandergeest. 2011. Political ecologies of war and forests: Counterinsurgencies and the making of national natures. Annals of the Association of American Geographers, 101 (3), 587-608.

Perpres. 2005a. Pengadaan Tanah Bagi Pelaksaan Pembangunan Untuk Kepentingan Umum. Peraturan Presiden Republik Indonesia, Perpres, No. 36.

Perpres. 2005b. Rencana Tata Ruang Kawasan Perbatasan Negara Di Kalimantan. Jakarta: Peraturan President Republik Indonesia, Draft KE-14, Direktorat Jenderal Penataan Ruang.

Perpres. 2010a. Badan Nasional Pengelola Perbatasan. Jakarta: Peraturan Presiden Republik Indonesia, No. 12.

Perpres. 2010b. Rencana Pembangunan Janka Menengah National (Rpjmn). Tahun 2010-2014. Peraturan Presiden Republik Indonesia, No. 5.

Persero. 2005. Pembangunan Kawasan Perbatasan Melalui Pembangunan Perkebunan Kelapa Sawit Di Propinsi Kalimantan Barat. Jakarta: PT Perkebunan Nusantara 1-XIV (Persero).

Persoon, G.A. and M. Osseweijer. 2008. Reflections on the Heart of Borneo. Wageningen. The Netherlands: Tropenbos International.

PKB. 2005a. Menteri Pembangunan Daerah Tertinggal Adakan Kunjungan Kerja Kalbar. Berita Pemerintah Kalimantan Barat.

PKB. 2005b. Presiden Sby: Kalbar Sangat Potensial Untuk Maju. Berita Pemerintah Kalimantan Barat.

Pontianak Post. 2005. Tni Ad Dukung Sawit Perbatasan. Pontianak Post, 1 Dec.

Potter, L. 2009. Resource periphery, corridor, Heartland: Contesting land use in the Kalimantan/ Malaysia Borderlands. Asia Pacific Viewpoint, 50(1), 88-106.

Potter, L. 2011. Agrarian transitions in Kalimantan: Characteristics, limitations and accommodations. In: R.D. Koninck, S. Bernard and J.-F. Bissonnette, eds. Borneo transformed: Agricultural expansion on the Southeast Asian Frontier. Singapore: NUS Press, pp. 152-202.

Potter, L. 2012. New transmigration 'paradigm' in Indonesia: Examples from Kalimantan. Asia Pacific Viewpoint, 53(2), 272-287.

PTPN. 2006. Lahan Sawit Di Perbatasan Malaysia Sempit China Batalkan Rencana Investasi. Jakarta: PT. Kharisma Pemasaran Bersama Nusantara.

Puslitbangtrans. 2005. Pengembangan Model Transmigrasi Terpadu Di Wilayah Perbatasan. Jakarta: Pusat Litbang Ketransmigrasian.

Redclift, M.R. 2006. Frontiers: Histories of civil society and nature. Cambridge, Massachusetts: MIT Press.

Scott, J.C. 1998. Seeing like a state: How certain schemes to improve the human condition have failed. New Haven: Yale University Press.

Sinar Harapan. 2004. Pembalakan liar di perbatasan Indonesia-Malaysia (2): Korupsi, judi dan narkoba jadi pemicu konflik, 6 May.

Soemadi. 1974. Peranan Kalimantan Barat Dalam Menghadapi Subversi Komunis Asia Tenggara: Suatu Tinjauan Internasional Terhadap Gerakan Komunis Dari Sudut Pertahanan Wilayah Khususnya Kalimantan Barat. Pontianak: Yayasan Tanjungpura.

Suara Bekakak. 2006. Kawasan Perbatasan Bukan Untuk Sawit, Masyarakat Berdaulat Atas Pengelolaan Sumber Daya. Suara Bekakak: Berita triwulan Taman Nasional Danau Sentarum, Jul-Sep.

Subritzky, J. 2000. Confronting Sukarno. New York: St. Martins Press.

Tempo. 2005. Border integrity, Tempo, English edition No. 50. 16-22 Aug.

Tempo. 2011. Malaysia violates Kalimantan border. Tempo Interactive, 11 Oct.

The Star. 2010. Sarawakians urged to invest in West Kalimantan border projects, The Star, 14 Apr. 
The Wall Street Journal. 2005. Jobs Vs. Jungle in Borneo. The Wall Street Journal, 4-6 Nov.

Tsing, A.L. 2000. Inside the economy of appearances. Public Culture, 12(1), 115-144.

Tsing, A.L. 2003. Natural resource and capitalist frontiers. Economic \& Political Weekly, 38(48), 5100-5106.

Tsing, A.L. 2005. Friction: An ethnography of global connection. Princeton, NJ: Princeton University Press.

Tuck, C. 2004. Borneo 1963-66: Counter-insurgency operations and war termination. Small Wars and Insurgencies, 15(3), 89-111.

Van Schendel, W. 2005. Spaces of engagement: How borderlands, illicit flows, and territorial states interlock. In: W. van Schendel and I. Abrahams, eds. Illicit flows and criminal things: States, borders, and the other side of globalization. Bloomington and Indianapolis: Indiana University Press, pp. 38-68.

Vandergeest, P. and N. Peluso. 1995. Territorialization and State Power in Thailand. Theory and Society, 24, 385-426.

Wadley, R.L. 1998. The road to change in the Kapuas Hulu Borderlands: Jalan Lintas Utara. Borneo Research Bulletin, 29, 71-94.

Wadley, R.L. 2005. Boundaries, territory and resource access in West Kalimantan, Indonesia 18002000. In: R.L. Wadley, ed. Histories of the Borneo environment: Economic, political, and social dimensions of change and continuity. Verhandelingen van het Koninklijk Instituut voor Taal-, Land- en Volkenkunde 231. Leiden, Netherlands: KITLV Press, pp. 137-158.

Wadley, R.L. and M. Eilenberg. 2005. Autonomy, Identity, and 'Illegal' Logging in the Borderland of West Kalimantan, Indonesia. Asia Pacific Journal of Anthropology, 6(1), 19-34.

Wakker, E. 2006. The Kalimantan border oil palm mega-project. Amsterdam: AIDEnvironment.

WALHI. 2007. There is still military in the forest. Indonesian Forum for Environment (WALHI), 27 Jun.

Walker, A. 1999. The legend of the golden boat: Regulation, trade and traders in the Borderlands of Laos, Thailand, Burma and China. Surrey, UK: Curzon Press.

Walker, A. 2006. Beyond hills and plains: Rethinking trade, state and society in the upper Mekong Borderlands. In: W. van Schendel, ed. Underworlds and Borderlands. IIAS Newsletter 42 (Special Issue, Sept 2006), p. 5.

Wendl, T. and M. Rösler. 1999. Introduction: Frontiers and Borderlands. The rise and relevance of an anthropological research genre. In: M. Rösler and T. Wendl, eds. Frontiers and Borderlands: Anthropological perspectives. Frankfurt am Main: Peter Lang, pp. 1-27.

Winichakul, T. 1994. Siam Mapped. A history of the geo-body of a nation. Honolulu: University of Hawaii Press.

Wollenberg, E., M. Moeliono, G. Limberg, R. Iwan, S. Rhee and M. Sudana. 2006. Between state and society: Local governance of forests in Malinau, Indonesia. Forest Policy and Economics, 8(4), 421-433.

Woods, K. 2011. Ceasefire capitalism: Military-private partnerships, resource concessions and military-state building in the Burma-China Borderlands. Journal of Peasant Studies, 38(4), 747-770.

WWF. 2005. World's largest oil palm plantation could spell disaster for upland forests of Indonesian Borneo. World Wide Fond for Nature.

Yong, K.H. 2006. Silences in history and nation-state: Reluctant Accounts of the Cold War in Sarawak. American Ethnologist, 33, 462-473.

Zaum, D. 2007. The souvereignty paradox: The norm and politics of international statebuilding. New York: Oxford University Press.

Michael Eilenberg is an Assistant Professor in Anthropology in the Department of Culture and Society, Aarhus University, Denmark. His research focuses on issues of state formation, sovereignty, autonomy, citizenship and agrarian expansion in frontier regions of Southeast Asia. He is the author of At the edges of states: dynamics of state formation in the Indonesian borderlands (KITLV Press, 2012). In 2011-2012 he was a Visiting Professor at the Department of Anthropology, University of Toronto, and in 2013 a Visiting Scholar at the Department of Environmental Science, Policy, and Management, University of California, Berkeley. Email: michael@eilenberg.dk, web: www. eilenberg.dk 